Boise State University

ScholarWorks

Organizational Performance and Workplace

Learning Faculty Publications and

Department of Organizational Performance and

Presentations

Workplace Learning

2019

Developing Team Creativity: The Influence of Psychological Safety and Relation-Oriented Shared Leadership

Soo Jeoung Han

Boise State University

Yunsoo Lee

Korea University

Michael Beyerlein

Texas A\&M University

This is the peer reviewed version of the following article:

Han, S.J.; Lee, Y.; \& Beyerlein, M. (2019). Developing Team Creativity: The Influence of Psychological Safety and Relation-Oriented Shared Leadership. Performance Improvement Quarterly, 32(2), 159-182.

which has been published in final form at doi: 10.1002/piq.21293. This article may be used for non-commercial purposes in accordance with Wiley Terms and Conditions for Self-Archiving. 


\title{
Developing Team Creativity: The Influence of Psychological Safety and Relation-Oriented Shared Leadership
}

\author{
Soo Jeoung Han \\ Boise State University \\ Boise, ID
}

\author{
Yunsoo Lee \\ Korea University \\ Seoul, North Korea
}

\author{
Michael Beyerlein \\ Texas A\&M University \\ College Station, TX
}

\begin{abstract}
This study examines the effects of a psychosocially safe environment and two types of shared leadership on project team creativity. We focused on specific dimensions of shared leadership to examine their association with creative outcomes. To measure the dimensions, we conducted a survey of 260 graduate and undergraduate students working in project teams at a large Southwestern university. We found that a psychologically safe environment enabled team members to perform task-oriented and relation-oriented tasks. However, only relation-oriented shared leadership positively influenced team creativity. Based on our findings, we provided research and practical implications, as well as study limitations and future research suggestions.
\end{abstract}

Keywords: psychological safety, shared leadership, team creativity

Collaboration helps solve complex problems by sharing different perspectives when working on a team project (Funk, 2014). Project require team members to perform a defined, specialized task within a definite time period (Chiocchio \& Essiembre, 2009). However, there seems to have been little attention paid to the study of ways team members create an effective team environment where collaboration enables creativity. This study examined the effects of a safe environment for collaboration and sharing the leadership role to unleash the creative capability of their teams.

Team creativity is essential when members collaborate to generate new ideas by synthesizing different ideas and values (Campbell, 1960; Hoever, Van Knippenberg, Van Ginkel, \& Barkema, 2012). While there are many studies on team creativity, very few studies have examined the effects of team contextual factors on team creativity (Shin, Kim, Lee, \& Bian, 2012; Zhu, Gardner, \& Chen, 2018). This is a critical omission from a theoretical standpoint because team creativity requires several conditions that enable contributions from all members to be crafted into joint solutions, such as working in a psychologically safe environment and having shared empowerment among team members.

Therefore, we examined the potential effects of psychological safety on shared leadership and team creativity because it represents the degree that members perceive the group as being a safe setting for interpersonal risk-taking (Edmondson, 1999). Since team creativity is difficult to achieve, we assumed that shared leadership would support it in a psychologically safe environment. For example, inclusive leadership positively relates to psychological safety, which, in turn, enhances team members' involvement in creative work (Carmeli, Reiter-Palmon, \& Ziv, 2010). However, a recent meta-analysis study by Hülsheger, Anderson, and Salgado (2009) failed to find a consistent effect of psychological safety on innovative team performance, suggesting the need for future research. Thus, we explored the simultaneous effects of team members' contextual factors on team creativity by introducing psychological safety and shared leadership.

In a leaderless group, shared leadership emerges as an evolving "mutual influence process" (Pearce, 2004, p. 48) and is "relationally produced, emerging through interactions and communication between actors in a context" (Denis, Langley, \& Sergi, 2012, p. 49). The literature has suggested that shared leadership can affect both team and individual outcomes (Nicolaides et al., 2014; Hülsheger et al., 2009). For example, shared leadership enhances individual creativity because team members tend to take the initiative to solve problems (Wood \& Fields, 2007). Although organizations and higher education institutions rely on team structures to increase creativity, many researchers primarily looked at creativity as an individual level phenomenon (Hirst, Van Knippenberg, \& Zhou, 2009; Kurtzberg 
This is an author-produced, peer-reviewed version of this article. The final, definitive version of this document can be found online at Performance Improvement Quarterly, published by Wiley on behalf of the International Society for Performance Improvement. Copyright restrictions may apply. doi: 10.1002/piq.21293

\& Amabile, 2001; Zhang, \& Bartol, 2010; Zhou \& George, 2003). More studies examining the effects of shared leadership on team creativity (e.g., Lee, Lee, \& Seo, \& Choi, 2015; Serban \& Roberts, 2016) are necessary as the concept represents a joint effort emerging from group interactions and activities, which may increase team creativity as a whole.

Since the mid-1990s, researchers have examined the value of shared leadership among team members but used various constructs (e.g., transformational, transactional, aversive, directive, and empowering leadership) and measurement strategies (i.e., aggregation methods, and social network approaches) to explore different behavioral forms of shared leadership (D’Innocenzo, Mathieu, \& Kukenberger, 2016). Conceptually, relation-oriented and taskoriented leadership have been part of the research literature since the 1950s (Halpin, 1957), but the previous research literature focused on the style of a formal leader. Bass (1991) suggested the distinction between these two orientations represented transactional and transformational leadership, so a number of studies have compared these two styles of leadership at the individual level. In contrast, shared leadership emerged as a team performance factor fairly recently (e.g., Pearce, 2004; Pearce \& Conger, 2002). However, empirical studies of the two dimensions of shared leadership have been rare. Our study adds value by examining the effects of the different dimensions of shared leadership on team creativity. This is the first study to use two dimensions from the Grille and Kauffeld's (2015) shared leadership scales.

To examine the relationships of a psychologically safe environment, shared leadership, and team creativity for team assignments, the following research question guided this inquiry: Do psychologically safe environments and shared leadership enable higher levels of team creativity?

\section{Literature Review and Hypotheses}

We reviewed scholarly articles that studied team psychological safety and shared leadership as potentially important factors in enabling creativity in project teams. Then, we reviewed antecedents of team creativity.

\section{$\underline{\text { Team Psychological Safety }}$}

Team member engagement in learning-oriented, knowledge-based work can be more effective when team members feel psychologically safe (Edmondson, 2004). Psychological safety implies that group members value each other's skills and talents, feel free to take risks, share information, and discuss mistakes without fear of retribution (Edmondson, 1999, 2002, 2012). Team psychological safety refers to a "shared belief that the team feels safe for interpersonal risk taking” (Edmondson, 1999, p. 354). Based on systematic literature review of psychological safety, 62 empirical studies have focused on the outcomes of psychological safety, such as performance, creativity, employee attitudes (e.g., positive attitudes towards teamwork), communication, knowledge sharing, and learning behaviors (Newman, Donohue, \& Eva, 2017).

Furthermore, team psychological safety is critical in relationship with team conflicts, because when team members experience high levels of team psychological safety initially followed by an increasing relationship conflict within the team over time, team identification decreased, resulting in lower satisfaction with the team (Johnson \& Avolio, 2018). Psychological safety appears to enable team members to use task conflict effectively to generate more creative ideas and critically discuss decisions, without taking the constructive conflict personally (Bradley, Postlethwaite, Klotz, Hamdani, \& Brown, 2012). Therefore, psychological safety has relevance to team processes (e.g., shared leadership) as well as team creative outcomes.

\section{Shared Leadership}

Most work on leadership has focused on traditional leadership in which one individual projects downward influence on organizational members (Pearce \& Sims, 2000). However, as teams become more complex, shared leadership may be more effective for leading teams (Pearce, Manz, \& Sims, 2009; Pearce \& Sims, 2000). A growing number of studies have examined shared leadership in teams (i.e., collective leadership and distributed leadership), and scholars noted that shared team leadership can affect team effectiveness (Day, Gronn, \& Salas, 2004; Han, Lee, Beyerlein, \& Kolb, 2018; Marks, Mathieu, \& Zaccaro, 2001: Mathieu, Maynard, Rapp, \& Gilson, 2008). 
This is an author-produced, peer-reviewed version of this article. The final, definitive version of this document can be found online at Performance Improvement Quarterly, published by Wiley on behalf of the International Society for Performance Improvement. Copyright restrictions may apply. doi: 10.1002/piq.21293

Although scholars have recently suggested a variety of definitions of shared leadership (Carson, Tesluk, \& Marrone, 2007; Pearce \& Conger, 2002; Pearce \& Sims, 2000; Zhou, 2012), we found similar characteristics among these definitions (Day, Gronn, \& Salas, 2004). Shared leadership acknowledges the interdependent nature of leadership through "collective achievement, shared responsibility, and the importance of teamwork" (Fletcher \& Käufer, 2003, p. 23). We adopted Carson et al.’s (2007, p. 1218) definition of shared leadership as "an emergent team property that results from the distribution of leadership influence across multiple team members”. According to Carson et al. (2007), leadership originates from individual team members taking responsibility for activities that influence the other team members through interaction. As a result, a leadership network shapes and influences the whole team's actions and outcomes. Under the concept of shared leadership, task-oriented and relation-oriented shared leadership were categorized separately (Grille \& Kauffeld, 2015), so we have chosen these two sub-concepts of shared leadership.

Task-Oriented Shared Leadership (TOSL). A task process consists of the activities that team members deliberately execute to achieve a goal. TOSL indicates team members sharing concern for achieving a good standard of performance (Grille \& Kauffeld, 2015). Behaviors related to task-oriented leadership include coordination activities, such as organizing work, assigning work to team members, and explaining rules and standard procedures (Yukl, Gordon, \& Taber, 2002). Explicit communication supports what needs to be done and how it should be done to promote effective team performance. To explain whether and how TOSL relates to team creativity, we adopt the information exchange perspective (Mesmer-Magnus \& DeChurch, 2009), which covers knowledge exchange and taskoriented communication related to the generation of creative ideas (Smith, Collins, \& Clark, 2005). Information exchange is an important process linked to team creativity because sharing task-relevant information leads to more thorough and creative information processing, problem solving, and decision making (Van Knippenberg, De Dreu, \& Homan, 2004).

Relation-Oriented Shared Leadership (ROSL). Relation-oriented team processes enhance the emotional strength of a team, such as support and collaboration, resulting in both positive team attitudes and increased performance (Mannix \& Neale, 2005; Thilo, 2005). ROSL behaviors include respecting team members' opinions and connecting emotionally to members (Yukl et al., 2002). Effective team members practice a variety of positive socio-emotional behaviors, such as supporting team members and showing consideration for the needs and feelings of others (Yukl et al., 2002). Likewise, shared team leadership is one of the important process factors that leads to team creativity and performance (Wang, Waldman, \& Zhang, 2014). Therefore, it is important to examine what team members share in what kind of context, and learn how shared leadership affects different output variables. In this paper, we will examine team creativity as our output variable, as discussed in the next section.

\section{$\underline{\text { Team Creativity }}$}

Researchers have begun to study how team creativity can be enhanced as many project teams desire to produce creative outcomes (Joo, Song, Lim, \& Yoon, 2012; Zhu et al., 2018). Team creativity can be defined as the "joint novelty and usefulness of a final idea developed by a group of people” (Hoever et al., 2012, p. 983). Although many studies explored a concept of creativity at the individual level, researchers have only recently started to examine team creativity as one of the key factors for organizational success (Perry-Smith \& Shalley, 2014).

Researchers have found both positive and negative antecedents of team creativity. For example, inhibitors to team creativity may include distrust between team leaders and members, personality differences, and generational differences in viewpoints (Han, Chae, Macko, Park, \& Beyerlein, 2017). Rosso (2014) also found that lacking time, equipment, and human resources can be top constraints for R\&D team creativity. On the other hand, the need for an integration of ideas and perspective taking is key in fostering team creativity, as creative solutions are required in complex situations (Hoever et al., 2012). In addition, Zhu et al. (2018) found that a collaborative team climate can be positively related to creativity. Specifically, team creativity researchers suggest that team members who feel psychologically safe may contribute unique expertise and insights, so they cooperatively craft inputs into useful and original solutions (Han et al., 2017; West, 2002). 
This is an author-produced, peer-reviewed version of this article. The final, definitive version of this document can be found online at Performance Improvement Quarterly, published by Wiley on behalf of the International Society for Performance Improvement. Copyright restrictions may apply. doi: 10.1002/piq.21293

\section{$\underline{\text { Hypothesized Research Model }}$}

The model was framed by using the perspective of the traditional input-process-outcome (IPO) model to illustrate the pattern of emergent team processes. The IPO framework has served as a major team model for decades (Salas, Stagl, \& Burke, 2004). For this study, the team input (team psychological safety) was identified as team process enablers. The team processes (shared leadership) were used to capture team dynamics, and the team output was used as team outcomes (team creativity).

Creativity can seem risky because it introduces novel ideas that other members are likely to reject. Consequently, behavior cues from other members that signal psychological safety act as important contextual variables related to creativity (George, 2007). When team members feel psychologically safe sharing creative ideas, they are more likely to come up with innovative solutions and engage in initiative and proactive behaviors (Edmondson, 2004; Kark \& Carmeli, 2008; Zhang \& Bartol, 2010). Psychological safety increases the likelihood that team members feel free to question suggestions and decisions without fear of negative interpersonal consequences, so they tend to behave more creatively (Burke, Stagl, Salas, Pierce, \& Kendall, 2006). Over time, members who had the opportunity to explain their new ideas were more creative than members that had been given no voice (Streicher, Jonas, Maier, Frey, \& Spießberger, 2012). Under a low level of psychological safety, people may feel helpless or at risk when speaking, which hinders their attempts at creativity (Baer \& Frese, 2003). Psychological safety will thus influence the team's creativity. Based on the literature review, we suggest the following hypotheses:

Hypothesis 1: Psychological safety among team members positively affects team creativity.

Psychological safety and empowerment can also affect teams in terms of task- and relation-oriented shared leadership (Carson et al., 2007; Grille, Schulte, \& Simone Kauffeld, 2015). A sense of psychological safety within the team enables members to enhance TOSL by opening up to feedback from others and encouraging knowledge sharing, which affects the degree to which team members accept mutual performance monitoring (Robson, Katsikeas, \& Bello, 2008; Yagil \& Luria, 2010). Concerning ROSL, psychological safety provides the opportunity to enhance the quality of interpersonal relationships within the team (Yagil \& Luria, 2010). Positive interpersonal relationships relate to willingness to support other members, share experiences and expertise, and identify opportunities for common improvement (Rhee, 2007; Yagil \& Luria, 2010). Creating a safe environment encourages learning for team members through sharing their experiences (Merriam, Caffarella, \& Baumgartner, 2012). Individuals who trust and get along well with each other effectively share knowledge without fear (Choo, Linderman, \& Schroeder, 2007, Kostopoulos \& Bozionelos, 2011). Therefore, we hypothesize that:

Hypothesis 2: Psychological safety positively affects task-oriented shared leadership.

Hypothesis 3: Psychological safety positively affects relation-oriented shared leadership.

We also argue that shared leadership has a positive effect on team creativity. Previous studies have shown that shared leadership can enhance individual creativity (Wood \& Fields, 2007), as well as team creativity when mediated by team processes experienced by team members (Gu, Chen, Huang, Liu, \& Huang, 2016; Hülsheger et al., 2009; Kirkman \& Rosen, 1999; Lee et al., 2015)A meta-analytic study summarizing 30 years of creativity research (Hülsheger et al., 2009) found that team processes, such as task-orientation and team cohesion, better predict team creativity than individual creativity. According to a recent empirical study, shared leadership related positively to both team creativity and individual creativity via knowledge sharing (Gu et al., 2016). Lee et al. (2015) reported that shared leadership positively contributed to team creativity. When it comes to a creative task, Serban and Roberts (2016) found that task cohesion was positively associated with shared leadership, which improved task satisfaction of a team. Interestingly, teams seem to require relational processes over time, whereas task-oriented processes are temporary (Amabile, Barsade, Mueller, \& Staw, 2005). Integrating TOSL with information exchange perspectives and ROSL, we argue that shared team leadership motivates team creativity. Therefore, we propose the hypotheses below:

Hypothesis 4: Task-oriented shared leadership among team members positively affects team creativity.

Hypothesis 5: Relation-oriented shared leadership among team members positively affects team creativity. 
This is an author-produced, peer-reviewed version of this article. The final, definitive version of this document can be found online at Performance Improvement Quarterly, published by Wiley on behalf of the International Society for Performance Improvement. Copyright restrictions may apply. doi: 10.1002/piq.21293

Figure 1 depicts the hypothesized relationships in the research model. We examined how the two dimensions of shared leadership play a role when considering a psychologically safe team environment on team creativity. We then focused on the logic behind the mediating effects of two dimensions of shared leadership between psychological safety and team creativity. The support behind the mediation effects is based on a conceptual framework of antecedents and outcomes of shared leadership (Kang and Svensson, 2018) and an empirical study (Serban \& Roberts, 2016). Both argued that one of the antecedents of shared leadership is having a supportive environment, and outcomes of shared leadership include creativity and performance. Lastly, we have included several control variables in the research model to focus on the relationship among team process factors.

\section{[Insert Figure 1 about here]}

\section{Methods}

\section{$\underline{\text { Sample and Data Collection }}$}

We invited students from organized graduate and undergraduate courses in an educational human resource development department at a large Southwestern university. Most of those teams conduct a project involving organizational clients in the profit or not-for-profit sectors lasting from four to ten weeks during the semester. Projects typically involve the following phases: build a relationship with the client, write a proposal approved by client and instructor, prepare questions for survey or interview data collection, collect and analyze data, write a report concluding with recommendations, and present the findings in a meeting with the client. Some of the teams attend class on campus and thus have the opportunity to meet face-to-face, supplementing meetings with electronic communications. Other classes are online with students geographically dispersed; thus they work virtually, relying on electronic communication devices all or most of the time. Online and offline teams meet the same project requirements, although online teams rely more on virtual collaboration.

The students represented both undergraduate and graduate levels. As a part of convenience sampling, all instructors in the department received invitations to involve their students in the study. Out of 20 faculty members, half of them agreed to encourage students to participate in this study. This study collected data through online-questionnaires about four weeks into the semester, and 287 students participated in the online survey. Of the 287 students, a subset of 260 provided usable data.

\section{$\underline{\text { Measures }}$}

We conducted an online survey about one month after the semester began to examine team members' perceptions of psychological safety, shared leadership, and team creativity. The survey questionnaire consisted of scales representing the variables described above with course and team identifiers.

Team Psychological Safety. Edmondson's (1999) team psychological safety scale was used to assess team members' perceptions. The psychological safety scale consists of seven items on a 5-point Likert-type scale. A sample item is: "Working with members of this team, my unique skills and talents are valued and utilized." Cronbach's alpha for this scale was .82. The reliability, validity, and factor structure of the measure were reported in Edmondson's (1999) study.

Shared Leadership. We assessed shared leadership with the questionnaire by Grille and Kauffeld (2015). The questionnaire measures four different aspects of shared leadership behavior: task-, relation-, change-, and micropoliticoriented leadership using 5-point Likert-type scales. The four scales demonstrated good measurement qualities in a confirmatory factor analysis in two independent German samples (Grille \& Kauffeld, 2015). For this study, we used the task-oriented leadership scale and the relation-oriented shared leadership scale because change- and micropoliticaloriented leadership dimensions are more relevant to a corporation setting than a higher education setting. Cronbach's alpha of the TOSL scale was .81 in study 1 and .84 in study 2; the ROSL scale was .88 in study 1 and .91 in study 2, respectively (Grille \& Kauffeld, 2015). In their studies, Confirmatory Factor Analysis provided evidence of discriminant validity. In addition, the two scales correlated with related measures, such as transformational and transactional leadership, providing evidence of convergent validity. The TOSL scale consists of items such as: "As a team we ensure that everyone knows their tasks." The ROSL scale consists of items such as: "We support each other in handling conflicts within the team.” 
This is an author-produced, peer-reviewed version of this article. The final, definitive version of this document can be found online at Performance Improvement Quarterly, published by Wiley on behalf of the International Society for Performance Improvement. Copyright restrictions may apply. doi: 10.1002/piq.21293

Team Creativity. We asked for individual team members' perceptions about their team's creativity using three items on a five-point scale (Kratzer, Leenders, and Van Engelen, 2010), such as, "how would you rate the newness and originality of the solutions your team finds to problems?” Cronbach’s alpha for this scale was .86.

Control Variables. First, we collected data of possible correlates of the main variables as possible demographic controls, such as age, gender $(0=$ female and $1=$ male $)$, and level of education $(0=$ undergraduate and $1=$ graduate). Second, we controlled for the following variables: course type $(0=$ offline, $1=$ online), extent of rich communication media use, and number of team members.

In terms of online and offline media richness, we used an existing measure of electronic communication dependence (Kirkman, Rosen, Tesluk, \& Gibson, 2006). Possible media choices included face-to-face meetings, videoconferencing, teleconferencing, discussion boards, email, instant messaging, knowledge repositories, and planning and scheduling tools. We asked participants to report the percentage of time they spent using each type of media when carrying out work, with their percentages summing to 100 percent. Communication media that are synchronous occurs in real time and allows non-verbal communication that are generally regarded as richer media (Kirkman \& Mathieu, 2005); therefore, we classified face-to-face meetings, video-conferencing, and teleconferencing as richer communication media, as compared with the other options. We then aggregated the percentage of time spent in face-to-face meetings, video-conferencing, and teleconferencing as a measure of rich communication to indicate how often team members used these three forms of media.

\section{$\underline{\text { Analysis }}$}

To examine the hypothesized model, the present study adopted structural equation modeling (SEM). In the present study, SEM analysis was performed using the AMOS statistical package (version 20), and thus a full-information maximum likelihood (FIML) was adopted to address missing values. To evaluate the fitness of the research model as well as alternative models, this study used the Tucker-Lewis index (TLI $\geq .90, \mathrm{Hu} \&$ Bentler, 1999), the comparative fit index (CFI; $\geq .90, \mathrm{Hu} \&$ Bentler, 1999), the root mean square error of approximation (RMSEA; $\leq .08$, Browne \& Cudeck, 1993), and the standardized root mean square residual (SRMR; $\leq .08$, Hu \& Bentler, 1999). Finally, as this study used cross-sectional data, Harman's single-factor test (Harman, 1967) was conducted to identify the common method variance bias.

\section{Data Analysis and Results}

In this section, we discussed the process of data analysis and its results. Most participants were female (66.5\%), white (60.0\%), undergraduate students (70.0\%), majoring in the same department (65.8\%) with a mean age of 24.6. Table 1 shows the demographics of the participating students. We investigated students' ethnicity, education level, gender, and course type, and the number of students in each team.

[Insert Table 1 about here]

\section{Verification of Validity and Reliability}

To check the quality of the scales, we performed a Confirmatory Factor Analysis and calculated Cronbach's $\alpha$ in order to verify scale validity and reliability. According to the results, the factor loading of all items on its respective latent variable was significant and higher than .05. Each variable (psychological safety .702; TOSL .867; ROSL.883; creativity .864) also met the criterion Cronbach's $\alpha$ of .60 (Van de Ven \& Ferry, 1980) for internal consistency.

We conducted Harman's single-factor test (Harman, 1967) in order to check the common method bias. The analysis revealed two factors with eigenvalues greater than 1.00 among four factors; no single factor explained a majority of the variance (the first factor explaining $35.661 \%$ ). This indicates that the common method bias is not a serious issue in this study.

\section{Descriptive Statistics and Correlation Analysis}

Means, standard deviations, skewness, kurtosis, and correlation were calculated. The mean and standard deviation of age were 24.57 and 7.11, and the mean and standard deviation of team size were 3.16 and 1.69, respectively. Team size ranged from three to eight. The mean and standard deviation of all study variables in this study showed 
This is an author-produced, peer-reviewed version of this article. The final, definitive version of this document can be found online at Performance Improvement Quarterly, published by Wiley on behalf of the International Society for Performance Improvement. Copyright restrictions may apply. doi: 10.1002/piq.21293

distributions from 3.62 to 3.98 , and from .56 to .68 on five-point scales, respectively. The normality assumption was also satisfied (skewness $<2$, kurtosis $<7$; West, Finch, \& Curran, 1995). Correlations are presented in Table 2. Correlations among the study variables were statistically significant ranging from $r=.376$ to $r=.773$. The result of collinearity diagnostics indicated that multi-collinearity did not occur $(r<.90$; tolerance $>0.1$; VIF $<10$; Kline, 2005).

[Insert Table 2 about here]

\section{Analyses of the Structural Models}

Table 3 presents the fitness indices for research models. To evaluate the fitness of the structural model, this study used TLI, CFI, RMSEA, and SRMR. These indexes pursue parsimony of the model and are relatively less sensitive to the sample size than other indexes (Browne \& Cudeck, 1993). The results indicated that the data fit the structural model.

[Insert Table 3 about here]

Table 4 shows the results of research model from Figure 1 (Model 1) and the results after the addition of the control variables (Model 2). The results of Model 2 indicated that no control variables showed significant relationships in the model with this data set except for the parameter from team size to TOSL.

[Insert Table 4 about here]

Psychological safety had a positive impact on both TOSL $(\beta=.705, p<.001$; supporting H2) and ROSL $(\beta=.698, p$ $<.001$; supporting H3), whereas the direct effect of psychological safety on team creativity was not significant, thus failing to support Hypothesis 1 . Interestingly, ROSL had a positive influence on team creativity $(\beta=.422, p<.05$; supporting H5), but the parameter between TOSL and creativity was not significant, thus failing to support H4.

Although both ROSL and TOSL are components of shared leadership and their correlation was .77 in the model, their relationships with creativity were quite different. Thus, we additionally analyzed Task-oriented Shared LeadershipMediating Model (TSMM) and Relation-oriented Shared Leadership-Mediating Model (RSMM), respectively. The goodness-of-fit indices of the TSMM (TLI $=.921, \mathrm{CFI}=.940$, RMSEA $=.059$, and SRMR $=.0552)$ and RSMM (TLI $=.961, \mathrm{CFI}=.970$, RMSEA $=.041$, and SRMR $=.0458)$ met the criteria.

Table 5 shows the results of the TSMM and RSMM. In both models, psychological safety still had a positive effect on TOSL $(\beta=.702, p<.001)$ and ROSL $(\beta=.700, p<.001)$. The effect of psychological safety on creativity, like the previous analysis, was not significant in either model. Taken together, the reason the lack of a significant relationship between TOSL and creativity in TSMM was determined to be due to the high correlation between TOSL and ROSL, which warrants further investigation.

\section{[Insert Table 5 about here]}

A summary of the results of our hypotheses testing is depicted in Figure 2.

[Insert Figure 2 about here]

\section{Discussion}

In this study, we found that a psychologically safe environment and relation-oriented shared leadership promote creativity in team projects. Previous studies supported the importance of psychological safety in the development of shared leadership (e.g., Carmeli et al., 2010; Nembhard \& Edmondson, 2006). Our study expands the research of Edmondson and her colleagues (Edmondson, 1999, 2004; Nembhard \& Edmondson, 2006), by focusing on the effect of psychological safety on two specific aspects of shared leadership and team creativity.

Our study demonstrates the importance of psychological safety, which leads to ROSL, which enhances team creativity. When team members cultivate a social climate in which they feel safe to speak up, they may become more willing to improve ROSL, which results in openness to discuss new ideas with their team members and generate novel and useful solutions. The characteristics of ROSL include: (a) addressing each member's concerns, (b) recognizing good performance, (c) promoting team cohesion, and (d) supporting each other when handling conflicts within the team (Grille \& Kauffeld, 2015). Other researchers also support this relationship by arguing that social support promotes 
This is an author-produced, peer-reviewed version of this article. The final, definitive version of this document can be found online at Performance Improvement Quarterly, published by Wiley on behalf of the International Society for Performance Improvement. Copyright restrictions may apply. doi: 10.1002/piq.21293

creative teams (Madjar, Oldham, \& Pratt, 2002; Rhee, 2007), which not only expand individual members' cognitive and psychological resources, but also enhance synergistic dynamics among team members to elevate overall team creativity (Rhee, 2007). ROSL and team psychological safety act as prerequisites to performance, because in their absence, team members can be defensive or become silent when their ideas are criticized or rejected (Yaniv, 2004).

This study sheds light on the role of shared leadership because we found that team psychological safety leads to team creativity only when ROSL occurs. A direct relationship between psychological safety and team creativity did not occur when shared leadership was included in the model, which may clarify the claims of other scholars in the psychological safety and behavior literature (e.g., Baer \& Frese, 2003; Gong, Cheung, Wang, \& Huang, 2012). Although it may be true that a psychologically safe team environment can enhance team creativity, other variables seem to play important mediating roles in addition to ROSL. For example, positive group affective tone related to team creativity when team trust is low, which means that members might perceive conditions of psychological safety under these variable combinations (Tsai, Chi, Grandey, \& Fung, 2012). To further examine this possibility, it would be interesting to explore conditions where the joint influence of high levels of team psychological safety and TOSL might affect team creativity, such as routine work, complex projects, or large team sizes where a level of formal organization aids the group process. Researchers can also include different variables with shared leadership, such as trust or task-conflict, when looking at the effect of psychological safety on team creativity to clarify the relationship.

Interestingly, although the impact of ROSL in this model was statistically significant, we found that TOSL, such as monitoring a team's goals and assigning tasks, did not significantly affect team creativity. This seems to imply that close monitoring or controlling the behavior of team members may not lead to a members' creative output (e.g., George \& Zhou, 2001; Zhou, 2003), although that may be less likely in collectivist cultures (Hui, Au, \& Fock, 2004). Therefore, although the lack of a significant relationship between TOSL and creativity in this study seems surprising, the result does align with the aforementioned studies that have examined the negative effect of TOSL.

Additionally, in our model, no control variables, such as age, gender, education level, course type, and degree of media richness, showed significant relationships with the main variables except for the relationship of team size and TOSL. This suggests that as team size increases, TOSL increases, which may indicate that increased complexity created by adding members requires more attention to the organizing activities of TOSL. In this study, the highest response rates $(47.7 \%)$ involved groups of four members, and the largest teams included 7-8 members (23.8\%). As instructors tend not to design student teams with more than 10 students, we may interpret this result to suggest that large groups may perform well when using TOSL compared to a small group with 3-4 members - an implication worth further investigation.

In contrast to studies from 10 or 15 years ago, (e.g., Gurtner, Kolbe, \& Boos, 2007; Kirkman, Rosen, Tesluk, \& Gibson, 2004), we found no difference between virtual and face-to-face teams in their pattern of shared leadership and creativity. This suggests that virtual and face-to-face interactions may not be significantly different now due to the development of technology because virtual communication now enables immediate feedback through overcoming the limitations of time and space (Malhotra \& Majchrzak, 2014). According to a meta-analysis study with 1,105 experimental studies of technology use in higher education (Schmid et al., 2014), learning is best supported when each member is actively engaged via technological tools that provide cognitive support. This technology based learning culture may increase team members' potential to share leadership and develop creativity.

Finally, project team process interweaves task work with teamwork to achieve performance goals (Han \& Beyerlein, 2016), which typically requires creative thinking. Our findings suggest that TOSL (formal structure) becomes more important as the number of members increase, but that ROSL (informal structure) is essential for creativity in any size teams. Perhaps, the tipping point where adding TOSL helps with creativity represents a micro-level version of what Brown and Eisenhardt (1998) call the edge - a place where structure and chaos meet so that creative solutions emerge.

\section{Theoretical Implications}

The present findings have several implications for future research. This study is the first one to empirically test TOSL and ROSL as separate dimensions of shared leadership, thus adding to arguments advocating for their distinctiveness. We found that the effects of the two shared leadership dimensions on team creativity were different. This finding may lead to the refinement of existing studies that treated shared leadership as a unified construct (Arnold, Arad, Rhoades, \& Drasgow, 2000; Hon \& Chan, 2013; Lee et al., 2015). Our model indicates that the question of "what is shared" matters. Little literature exists about which dimensions of shared leadership may be most potent in influencing 
This is an author-produced, peer-reviewed version of this article. The final, definitive version of this document can be found online at Performance Improvement Quarterly, published by Wiley on behalf of the International Society for Performance Improvement. Copyright restrictions may apply. doi: 10.1002/piq.21293

different indicators of team creativity. Future researchers can examine shared leadership with these questions: what is shared among teams and under what conditions shared leadership behavior is most or least effective on team creativity and why?

Our model of how ROSL enhances team creativity may be especially impactful in certain kinds of work or at certain points in the creative process. The level of creativity required for a job may change the level of shared leadership and its empowerment relationship (Unsworth, Wall, \& Carter, 2005). For monotonous work low in task control, complexity, and significance (Ohly, Sonnentag, \& Pluntke, 2006), it may not be apparent that people can work collaboratively to lead creative efforts. Therefore, scholars should further examine the effect of ROSL in different contextual settings.

\section{Practical Implications}

The present findings have several implications for educators and managers in terms of instructional design, coaching, training, and learning culture. Instructors or managers can coach each team member to practice effective shared leadership behaviors and teaming behaviors that can help increase team creativity. In addition, instructors and managers need to acknowledge that modern day learning systems are more flexible and adaptable to different levels of learning strategies. Therefore, empowering team members to manage their own learning and foster creative thinking and action by creating positive and supportive environments is important to supplement the effect of formal courses. A psychologically safe environment can be viewed as a prerequisite in order for team members to have shared leadership, which may increase team creativity and group learning. Therefore, we recommend instructors and managers design team activities by considering psychological safety so that team members can remove their fear of sharing creative ideas.

\section{$\underline{\text { Limitations and Future Research Suggestions }}$}

We noted some limitations in this study. First, the generalizability of the results may be limited because the study used a sample of undergraduate and graduate students from one large Southwestern university in a single department. Second, the correlation between psychological safety and shared leadership was very high. Therefore, we cannot ignore the possibility of a suppression effect in the structural model. However, the result of confirmatory factor analysis showed that shared leadership consisted of two dimensions: ROSL and TOSL. The result of analysis of common methods bias and collinearity diagnostic also indicated that common methods bias and multicollinearity had not occurred. We recommend that future researchers study this model with a different sample and instruments. Third, we used a short time frame when measuring team creativity and other enabling variables. An early team climate of team members may be different from mature stages, which may occur at the end of a long semester (George \& Zhou, 2007). We encourage future researchers to use a longer timeframe when measuring team climate and team creativity to examine change over time in these important relationships. Fourth, we relied on self-report surveys. Future researchers can also include other sources (e.g., scoring rubrics for final products from instructors or evaluations from clients of projects).

\section{Conclusion}

This study has shown strong connections between a psychologically safe team environment and team creativity via relation-oriented shared leadership (ROSL) among team members, all of which are critical in improving team learning and performance. Overall, we learned the importance of examining separate behavioral dimensions of shared leadership when specifying a process model for team creativity. In addition to theoretical implications, we suggest to practitioners that team member interactions serve as the key mechanism that explain the relationship between psychological safety and team creativity. In other words, socio-emotional relations among team members and a positive interpersonal environment may enhance team creativity. Relations among team members should be foundational when collaborating in a project to achieve creative goals. 
This is an author-produced, peer-reviewed version of this article. The final, definitive version of this document can be found online at Performance Improvement Quarterly, published by Wiley on behalf of the International Society for Performance Improvement. Copyright restrictions may apply. doi: 10.1002/piq.21293

\section{References}

Amabile, T. M., Barsade, S. G., Mueller, J. S., \& Staw, B. M. (2005). Affect and creativity at work. Administrative Science Quarterly, 50(3), 367-403. doi:10.2189/asqu.2005.50.3.367

Arnold, J. A., Arad, S., Rhoades, J. A., \& Drasgow, F. (2000). The empowering leadership questionnaire: The construction and validation of a new scale for measuring leader behaviors. Journal of Organizational Behavior, 21(3), 249-269.

Baer, M., \& Frese, M. (2003). Innovation is not enough: Climates for initiative and psychological safety, process innovations, and firm performance. Journal of Organizational Behavior, 24(1), 45-68. doi:10.1002/job.179

Bass, B. M. (1991). From transactional to transformational leadership: Learning to share the vision. Organizational dynamics, 18(3), 19-31.

Bradley, B. H., Postlethwaite, B. E., Klotz, A. C., Hamdani, M. R., \& Brown, K. G. (2012). Reaping the benefits of task conflict in teams: the critical role of team psychological safety climate. Journal of Applied Psychology, 97(1), 151-158. doi:10.1037/a0024200

Brown, S. L., \& Eisenhardt, K. M. (1998). Competing on the edge: Strategy as structured chaos. Harvard Business Press.

Browne, M. W., \& Cudeck, R. (1993). Alternative ways of assessing model fit. In K. A. Bollen \& J. S. Long (Eds.), Testing structural equation model (pp. 136-162). Newbury Park, CA: Sage.

Burke, C. S., Stagl, K. C., Salas, E., Pierce, L., \& Kendall, D. (2006). Understanding team adaptation: a conceptual analysis and model. Journal of Applied Psychology, 91(6), 1189-1207. doi:10.1037/0021-9010.91.6.1189

Campbell, D. T. (1960). Blind variation and selective retentions in creative thought as in other knowledge processes. Psychological Review, 67(6), 380-400. doi:10.1037/h0040373

Carmeli, A., Reiter-Palmon, R., \& Ziv, E. (2010). Inclusive leadership and employee involvement in creative tasks in the workplace: The mediating role of psychological safety. Creativity Research Journal, 22(3), 250-260. doi:10.1080/10400419.2010.504654

Carson, J. B., Tesluk, P. E., \& Marrone, J. A. (2007). Shared leadership in teams: An investigation of antecedent conditions and performance. Academy of Management Journal, 50(5), 1217-1234. doi:10.2307/AMJ.2007.20159921

Chiocchio, F., \& Essiembre, H. (2009). Cohesion and performance: A meta-analytic review of disparities between project teams, production teams, and service teams. Small group research, 40(4), 382-420.

Choo, A. S., Linderman, K. W., \& Schroeder, R. G. (2007). Method and psychological effects on learning behaviors and knowledge creation in quality improvement projects. Management Science, 53(3), 437-450. doi:10.1287/mnsc.1060.0635

Day, D. V., Gronn, P., \& Salas, E. (2004). Leadership capacity in teams. The Leadership Quarterly, 15(6), 857-880. doi:10.1016/j.leaqua.2004.09.001

Denis, J. L., Langley, A., \& Sergi, V. (2012). Leadership in the plural. The Academy of Management Annals, 6(1), 211-283.

D’Innocenzo, L., Mathieu, J. E., \& Kukenberger, M. R. (2016). A meta-analysis of different forms of shared leadership-team performance relations. Journal of Management, 42(7), 1964-1991. doi:10.1177/0149206314525205

Edmondson, A. (1999). Psychological safety and learning behavior in work teams. Administrative Science Quarterly, 44(2), 350-383. doi:10.2307/2666999

Edmondson, A. C. (2002). Managing the risk of learning: Psychological safety in work teams. Division of Research, Harvard Business School.

Edmondson, A. C. (2004). Psychological safety, trust, and learning in organizations: A group-level lens. In R. M. Kramer \& K. S. Cook (Eds.), Trust and distrust in organizations: Dilemmas and approaches (pp. 239 272). New York, NY: Sage

Edmondson, A. C. (2012). Teaming: How organizations learn, innovate, and compete in the knowledge economy. John Wiley \& Sons.

Fletcher, J. K., \& Käufer, K. (2003). Shared leadership (pp. 21-47). C. L. Pearce, \& J. A. Conger (Eds.), Shared leadership: Reframing the hows and whys of leadership. Thousand Oaks, CA: Sage.

Funk, R. J. (2014). Making the most of where you are: Geography, networks, and innovation in organizations. Academy of Management Journal, 57(1), 193-222. doi:10.5465/amj.2012.0585

George, J. M. (2007). Creativity in organizations. Academy of Management Annals, 1(1), 439-477. doi:10.1080/078559814 
This is an author-produced, peer-reviewed version of this article. The final, definitive version of this document can be found online at Performance Improvement Quarterly, published by Wiley on behalf of the International Society for Performance Improvement. Copyright restrictions may apply. doi: 10.1002/piq.21293

George, J. M., \& Zhou, J. (2001). When openness to experience and conscientiousness are related to creative behavior: an interactional approach. Journal of Applied Psychology, 86(3), 513-524.doi:10.1037/00219010.86.3.513

George, J. M., \& Zhou, J. (2007). Dual tuning in a supportive context: Joint contributions of positive mood, negative mood, and supervisory behaviors to employee creativity. Academy of Management Journal, 50(3), 605622. doi:10.5465/AMJ.2007.25525934

Gong, Y., Cheung, S. Y., Wang, M., \& Huang, J. C. (2012). Unfolding the proactive process for creativity integration of the employee proactivity, information exchange, and psychological safety perspectives. Journal of Management, 38(5), 1611-1633. doi:10.1177/0149206310380250

Grille, A., \& Kauffeld, S. (2015). Development and Preliminary Validation of the Shared Professional Leadership Inventory for Teams (SPLIT). Psychology, 6, 75-92. doi:10.4236/psych.2015.61008

Grille, A., Schulte, E. M., \& Kauffeld, S. (2015). Promoting shared leadership: A multilevel analysis investigating the role of prototypical team leader behavior, psychological empowerment, and fair rewards. Journal of Leadership \& Organizational Studies, 22(3), 324-339.

Gu, J., Chen, Z., Huang, Q., Liu, H., \& Huang, S. (2016). A multilevel analysis of the relationship between shared leadership and creativity in inter-organizational teams. The Journal of Creative Behavior. Advance online publication. doi:10.1002/jocb.135

Gurtner, A., Kolbe, M., \& Boos, M. (2007). Satisfaction in virtual teams in organizations. The Electronic Journal for Virtual Organizations and Networks, 9, 9-29.

Han, S. J. \& Beyerlein, M. (2016). Framing the effects of multinational cultural diversity on virtual team processes. Small Group Research, 47(4), 1-33. doi:10.1177/1046496416653480

Han, S. J., Chae, C, Macko, P., Park, W., \& Beyerlein, M. (2017). How virtual team leaders cope with creativity challenges. European Journal of Training and Development, 41(3), 261-276. doi.org/10.1108/EJTD-102016-0073

Han, S. J., Lee, Y., Beyerlein, M., \& Kolb, J. (2018). Shared leadership in teams: The role of coordination, goal commitment, and knowledge sharing on perceived team performance. Team Performance Management: An International Journal, 24(3/4), 150-168. doi.org/10.1108/TPM-11-2016-0050

Halpin, A. W. (1955). The leader behavior and leadership ideology of educational administrators and aircraft commanders. Harvard Educational Review, 25, 18-32.

Harman, H. H. (1967). Modem factor analysis. Chicago: University of Chicago. Hirst, G., Van Knippenberg, D., \& Zhou, J. (2009). A cross-level perspective on employee creativity: Goal orientation, team learning behavior, and individual creativity. Academy of management journal, 52(2), 280-293.

Hoever, I. J., Van Knippenberg, D., Van Ginkel, W. P., \& Barkema, H. G. (2012). Fostering team creativity: perspective taking as key to unlocking diversity's potential. Journal of Applied Psychology, 97(5), 982-996. doi:10.1037/a0029159

Hon, A. H., \& Chan, W. W. (2013). Team creative performance the roles of empowering leadership, creative-related motivation, and task interdependence. Cornell Hospitality Quarterly, 54(2), 199-210. doi:10.1177/1938965512455859

Hu, L. T., \& Bentler, P. M. (1999). Cutoff criteria for fit indexes in covariance structure analysis: Conventional criteria versus new alternatives. Structural equation modeling: a multidisciplinary journal, 6(1), 1-55.

Hui, M. K., Au, K., \& Fock, H. (2004). Empowerment effects across cultures. Journal of International Business Studies, 35, 46-60.

Hülsheger, U. R., Anderson, N., \& Salgado, J. F. (2009). Team-level predictors of innovation at work: a comprehensive meta-analysis spanning three decades of research. Journal of Applied Psychology, 94(5), 1128-1145. doi:10.1037/a0015978

Johnson, H. H., \& Avolio, B. J. (2018). Team Psychological Safety and Conflict Trajectories' Effect on Individual's Team Identification and Satisfaction. Group \& Organization Management, 1059601118767316.

Joo, B. K. B., Song, J. H., Lim, D. H., \& Yoon, S. W. (2012). Team creativity: The effects of perceived learning culture, developmental feedback and team cohesion. International Journal of Training and Development, 16(2), 77-91. doi:10.1111/j.1468-2419.2011.00395.x

Kang, S., \& Svensson, P. G. (2018). Shared leadership in sport for development and peace: A conceptual framework of antecedents and outcomes. Sport Management Review.

Kark, R., \& Carmeli, A. (2009). Alive and creating: The mediating role of vitality and aliveness in the relationship between psychological safety and creative work involvement. Journal of Organizational Behavior, 30(6), 785-804. doi:10.1002/job.571 
This is an author-produced, peer-reviewed version of this article. The final, definitive version of this document can be found online at Performance Improvement Quarterly, published by Wiley on behalf of the International Society for Performance Improvement. Copyright restrictions may apply. doi: 10.1002/piq.21293

Kirkman, B. L., \& Rosen, B. (1999). Beyond self-management: Antecedents and consequences of team empowerment. Academy of Management Journal, 42(1), 58-74. doi:10.2307/256874

Kirkman, B. L., \& Mathieu, J. E. (2005). The dimensions and antecedents of team virtuality. Journal of Management, 31(5), 700-718. doi:10.1177/0149206305279113

Kirkman, B. L., Rosen, B., Tesluk, P. E., \& Gibson, C. B. (2004). The impact of team empowerment on virtual team performance: The moderating role of face-to-face interaction. Academy of Management Journal, 47(2), 175-192.

Kirkman, B. L., Rosen, B., Tesluk, P. E., \& Gibson, C. B. (2006). Enhancing the transfer of computer-assisted training proficiency in geographically distributed teams. Journal of Applied Psychology, 91(3), 706-716. doi:10.1037/0021-9010.91.3.706

Kline, R. B. (2005). Principles and practice of structural equation modeling (2nd ed.). New York: The Guilford Press.

Kostopoulos, K. C., \& Bozionelos, N. (2011). Team exploratory and exploitative learning: Psychological safety, task conflict, and team performance. Group \& Organization Management, 36(3), 385-415. doi:10.1177/1059601111405985

Kratzer, J., Leenders, R. T. A., \& Van Engelen, J. M. (2010). The social network among engineering design teams and their creativity: A case study among teams in two product development programs. International Journal of Project Management, 28(5), 428-436. doi:10.1016/j.ijproman.2009.09.007

Kurtzberg, T. R., \& Amabile, T. M. (2001). From Guilford to creative synergy: Opening the black box of team-level creativity. Creativity Research Journal, 13(3-4), 285-294. doi:10.1207/S15326934CRJ1334_06

Lee, D. S., Lee, K. C., Seo, Y. W., \& Choi, D. Y. (2015). An analysis of shared leadership, diversity, and team creativity in an e-learning environment. Computers in Human Behavior, 42, 47-56. doi:10.1016/j.chb.2013.10.064

Madjar, N., Oldham, G. R., \& Pratt, M. G. (2002). There's no place like home? The contributions of work and nonwork creativity support to employees' creative performance. Academy of Management Journal, 45(4), 757-767. doi:10.2307/3069309

Malhotra, A., \& Majchrzak, A. (2014). Enhancing performance of geographically distributed teams through targeted use of information and communication technologies. Human Relations, 67(4), 389-411.

Mannix, E., \& Neale, M. A. (2005). What differences make a difference? The promise and reality of diverse teams in organizations. Psychological Science in the Public Interest, 6(2), 31-55. doi:10.1111/j.15291006.2005.00022.x

Marks, M. A., Mathieu, J. E., \& Zaccaro, S. J. (2001). A temporally based framework and taxonomy of team processes. Academy of Management Review, 26(3), 356-376. doi:10.5465/AMR.2001.4845785

Mathieu, J., Maynard, M. T., Rapp, T., \& Gilson, L. (2008). Team effectiveness 1997-2007: A review of recent advancements and a glimpse into the future. Journal of management, 34(3), 410-476.

Merriam, S. B., Caffarella, R. S., \& Baumgartner, L. M. (2012). Learning in adulthood: A comprehensive guide. San Francisco, CA: Jossey-Bass.

Mesmer-Magnus, J. R., \& De Church, L. A. (2009). Information sharing and team performance: a meta-analysis. Journal of Applied Psychology, 94(2), 535-546. doi:10.1037/a0013773

Nembhard, I. M., \& Edmondson, A. C. (2006). Making it safe: The effects of leader inclusiveness and professional status on psychological safety and improvement efforts in health care teams. Journal of Organizational Behavior, 27(7), 941-966. doi:10.1002/job.413

Newman, A., Donohue, R., \& Eva, N. (2017). Psychological safety: A systematic review of the literature. Human Resource Management Review, 27(3), 521-535.

Nicolaides, V. C., LaPort, K. A., Chen, T. R., Tomassetti, A. J., Weis, E. J., Zaccaro, S. J., \& Cortina, J. M. (2014). The shared leadership of teams: A meta-analysis of proximal, distal, and moderating relationships. The Leadership Quarterly, 25(5), 923-942. doi:10.1016/j.leaqua.2014.06.006

Ohly, S., Sonnentag, S., \& Pluntke, F. (2006). Routinization, work characteristics and their relationships with creative and proactive behaviors. Journal of Organizational Behavior, 27(3), 257-279. doi:10.1002/job.376

Pearce, C. L. (2004). The future of leadership: Combining vertical and shared leadership to transform knowledge work. The Academy of Management Executive, 18(1), 47-57.

Pearce, C. L., \& Conger, J. A. (2002). Shared leadership: Reframing the hows and whys of leadership. Sage Publications.

Pearce, C. L., Manz, C. C., \& Sims, H. P. (2009). Where do we go from here? Is shared leadership the key to team success? Organizational Dynamics, 38(3), 234-238. 
This is an author-produced, peer-reviewed version of this article. The final, definitive version of this document can be found online at Performance Improvement Quarterly, published by Wiley on behalf of the International Society for Performance Improvement. Copyright restrictions may apply. doi: 10.1002/piq.21293

Pearce, C. L., \& Sims, H. P. (2000). Shared leadership: Toward a multi-level theory of leadership. Advances in Interdisciplinary Studies of Work Teams, 7, 115-139.

Perry-Smith, J. E., \& Shalley, C. E. (2014). A social composition view of team creativity: The role of member nationality-heterogeneous ties outside of the team. Organization Science, 25(5), 1434-1452. doi:10.1287/orsc.2014.0912

Rhee, S. Y. (2007). Group emotions and group outcomes: The role of group member interactions. In E. A. Mannix, M. A. Neale, \& C. P. Anderson (Eds.), Research on managing groups and teams (Vol. 10, pp. 65-96). Greenwich, CT: JAI Press

Robson, M. J., Katsikeas, C. S., \& Bello, D. C. (2008). Drivers and performance outcomes of trust in international strategic alliances: The role of organizational complexity. Organization Science, 19(4), 647-665. doi:10.1287/orsc.1070.0329

Rosso, B. D. (2014). Creativity and constraints: Exploring the role of constraints in the creative processes of research and development teams. Organization Studies, 35(4), 551-585. doi: 10.1177/0170840613517600

Salas, E., Stagl, K. C., \& Burke, C. S. (2004). 25 years of team effectiveness in organizations: research themes and emerging needs. International review of industrial and organizational psychology, 19, 47-92.

Schmid, R. F., Bernard, R. M., Borokhovski, E., Tamim, R. M., Abrami, P. C., Surkes, M. A., \& Woods, J. (2014). The effects of technology use in postsecondary education: A meta-analysis of classroom applications. Computers \& Education, 72, 271-291. doi:10.1016/j.compedu.2013.11.002

Serban, A., \& Roberts, A. J. (2016). Exploring antecedents and outcomes of shared leadership in a creative context: A mixed-methods approach. The leadership quarterly, 27(2), 181-199. doi:10.1016/j.leaqua.2016.01.009

Shin, S. J., Kim, T. Y., Lee, J. Y., \& Bian, L. (2012). Cognitive team diversity and individual team member creativity: A cross-level interaction. Academy of Management Journal, 55(1), 197-212. doi:10.5465/amj.2010.0270

Smith, K. G., Collins, C. J., \& Clark, K. D. (2005). Existing knowledge, knowledge creation capability, and the rate of new product introduction in high-technology firms. Academy of management Journal, 48(2), 346-357. doi:10.5465/AMJ.2005.16928421

Streicher, B., Jonas, E., Maier, G. W., Frey, D., \& Spießberger, A. (2012). Procedural fairness and creativity: Does voice maintain people's creative vein over time? Creativity Research Journal, 24(4), 358-363. doi:10.1080/10400419.2012.730334

Tsai, W. C., Chi, N. W., Grandey, A. A., \& Fung, S. C. (2012). Positive group affective tone and team creativity: Negative group affective tone and team trust as boundary conditions. Journal of Organizational Behavior, 33(5), 638-656. doi:10.1002/job.775

Thilo, J. L. (2005). Leadership in the ASC: Opportunity and responsibility. Ambulatory Surgery, 12(1), 11-14. doi:10.1016/j.ambsur.2005.02.005

Unsworth, K. L., Wall, T. D., \& Carter, A. (2005). Creative requirement a neglected construct in the study of employee creativity? Group \& Organization Management, 30(5), 541-560. doi: $10.1177 / 1059601104267607$

Van de Ven, A. H., \& Ferry, D. L. (1980). Measuring and Assessing Organizations, NY: Wiley.

Van Knippenberg, D., De Dreu, C. K., \& Homan, A. C. (2004). Work group diversity and group performance: An integrative model and research agenda. Journal of Applied Psychology, 89(6), 1008-1022. doi:10.1037/0021-9010.89.6.1008

Wang, D., Waldman, D. A., \& Zhang, Z. (2014). A meta-analysis of shared leadership and team effectiveness. Journal of Applied Psychology, 99(2), 181-198. doi:10.1037/a0034531

West, M. A. (2002). Sparkling fountains or stagnant ponds: An integrative model of creativity and innovation implementation in work groups. Applied Psychology, 51(3), 355-387. doi:10.1111/1464-0597.00951

West, S. G., Finch, J. F., \& Curran, P. J. (1995). Structural equation models with non-normal variables: Problems and remedies, in Hoyle, R. (Ed.), Structural Equation Modeling: Concepts, Issues and Applications (pp. 56-75), Newbury Park, CA: Sage.

Wood, M. S., \& Fields, D. (2007). Exploring the impact of shared leadership on management team member job outcomes. Baltic Journal of Management, 2(3), 251-272. doi:10.1108/17465260710817474

Yagil, D., \& Luria, G. (2010). Friends in need: the protective effect of social relationships under low-safety climate. Group \& Organization Management, 35(6), 727-750. doi:10.1177/1059601110390936

Yaniv, I. (2004). The benefit of additional opinions. Current Directions in Psychological Science, 13(2), 75-78. doi: 10.1111/j.0963-7214.2004.00278.x 
This is an author-produced, peer-reviewed version of this article. The final, definitive version of this document can be found online at Performance Improvement Quarterly, published by Wiley on behalf of the International Society for Performance Improvement. Copyright restrictions may apply. doi: 10.1002/piq.21293

Yukl, G., Gordon, A., \& Taber, T. (2002). A hierarchical taxonomy of leadership behavior: Integrating a half century of behavior research. Journal of Leadership \& Organizational Studies, 9(1), 15-32. doi:10.1177/107179190200900102

Zhang, X., \& Bartol, K. M. (2010). Linking empowering leadership and employee creativity: The influence of psychological empowerment, intrinsic motivation, and creative process engagement. Academy of Management Journal, 53(1), 107-128. doi:10.5465/AMJ.2010.48037118

Zhou, J. (2003). When the presence of creative coworkers is related to creativity: Role of supervisor close monitoring, developmental feedback, and creative personality. Journal of Applied Psychology, 88, 413-422.

Zhou, W. (2012). Moderating and mediating effects of shared leadership on the relationship between entrepreneurial team diversity and performance. City University of New York.

Zhou, J., \& George, J. M. (2003). Awakening employee creativity: The role of leader emotional intelligence. The Leadership Quarterly, 14(4), 545-568. doi:10.1016/S1048-9843(03)00051-1

Zhu, Y. Q., Gardner, D. G., \& Chen, H. G. (2018). Relationships between work team climate, individual motivation, and creativity. Journal of Management, 44(5), 2094-2115. doi: 10.1177/0149206316638161

\section{Table 1}

Demographic Information.

\begin{tabular}{llllll}
\hline Variable & $\mathrm{n}$ & $\%$ & Variable & $\mathrm{n}$ & $\%$ \\
\hline Ethnicity & 156 & 60.0 & Gender & & \\
White & 19 & 7.3 & Male & 87 & 33.5 \\
African American & 61 & 23.5 & Female & 173 & 66.5 \\
Hispanic & 18 & 6.9 & Course type & & \\
Asian & 1 & 0.4 & Online & 86 & 33.1 \\
Native American & 5 & 1.9 & Offline & 174 & 66.9 \\
Other & & & Members & & \\
Education level & 9 & 3.5 & Three & 21 & 8.1 \\
Freshman & 34 & 13.1 & Four & 124 & 47.7 \\
Sophomore & 76 & 29.2 & Five & 21 & 8.1 \\
Junior & 63 & 24.2 & Six & 32 & 12.3 \\
Senior & 74 & 28.5 & Seven & 11 & 4.2 \\
M.S. student & 4 & 1.5 & Eight & 51 & 19.6 \\
Ph.D. student & & Total & 260 & 100.0 \\
\hline
\end{tabular}


This is an author-produced, peer-reviewed version of this article. The final, definitive version of this document can be found online at Performance Improvement Quarterly, published by Wiley on behalf of the International Society for Performance Improvement. Copyright restrictions may apply. doi: 10.1002/piq.21293

\section{Table 2}

Means, Standard Deviations, Skewness, Kurtosis, and Correlations of Study Variables

\begin{tabular}{|c|c|c|c|c|c|c|c|c|c|c|}
\hline & 1 & 2 & 3 & 4 & 5 & 6 & 7 & 8 & 9 & 10 \\
\hline \multicolumn{11}{|l|}{ Control Variables } \\
\hline 1. Age & 1 & & & & & & & & & \\
\hline 2. Gender & $.205^{* *}$ & 1 & & & & & & & & \\
\hline 3. Team size & $-.305 * *$ & $-.275^{* *}$ & 1 & & & & & & & \\
\hline 4. Course type & $.622 * *$ & .048 & $-.430 * *$ & 1 & & & & & & \\
\hline 5. Richness & $-.462 * *$ & -.044 & $.586^{* *}$ & $-.677 * *$ & 1 & & & & & \\
\hline 6. Education level & $.660 * *$ & .016 & $-.485 * *$ & $.842 * *$ & $-.630 * *$ & 1 & & & & \\
\hline \multicolumn{11}{|c|}{ Independent \& Dependent Variables } \\
\hline 7. Psychological Safety & $-.284 * *$ & -.084 & .062 & $-.270 * *$ & $.221^{* *}$ & $-.210 * *$ & 1 & & & \\
\hline 8. TOSL & -.115 & -.093 & .097 & -.090 & .108 & -.032 & $.506^{* *}$ & 1 & & \\
\hline 9. ROSL & $-.216^{* *}$ & -.096 & $.143^{*}$ & $-.225^{* *}$ & $.193 * *$ & $-.170 * *$ & $.549 * *$ & $.773 * *$ & 1 & \\
\hline 10. Creativity & $-.163^{* *}$ & $-.122 *$ & .084 & -.107 & .105 & $-.123^{*}$ & $.376^{* *}$ & $.429 * *$ & $.478 * *$ & 1 \\
\hline$M$ & 24.57 & & 3.16 & & & & 3.98 & 3.87 & 3.90 & 3.62 \\
\hline$S D$ & 7.11 & & 1.69 & & & & .56 & .68 & .64 & .67 \\
\hline Skewness & & & & & & & -.363 & -.615 & -.346 & -.365 \\
\hline Kurtosis & & & & & & & -.145 & 1.117 & 1.131 & .836 \\
\hline
\end{tabular}

Note: TOSL: Task-oriented Shared Leadership; ROSL: Relation-oriented Shared Leadership $* * * p<.001$ 
This is an author-produced, peer-reviewed version of this article. The final, definitive version of this document can be found online at Performance Improvement Quarterly, published by Wiley on behalf of the International Society for Performance Improvement. Copyright restrictions may apply. doi: 10.1002/piq.21293

\section{Table 3}

Fit Indices for Models

\begin{tabular}{lllllll}
\hline & $\chi^{2}$ & $\mathrm{df}$ & TLI & CFI & RMSEA (CI) & SRMR \\
\hline Criteria & & & $>.900$ & $>.900$ & $<.08$ & $<.08$ \\
Model 1 & $323.263^{* * *}$ & 164 & .926 & .936 & $.061(.051, .071)$ & .0510 \\
Model 2 & $467.125 * * *$ & 260 & .923 & .938 & $.055(.047, .063)$ & .0518 \\
\hline
\end{tabular}

Note: As Model 1 and Model 2 (with and without control variables) are saturated models, each model has the same model fit indices with its measurement model.

$* * * p<.001$

\section{Table 4}

Results of Research Models

\begin{tabular}{|c|c|c|c|c|c|c|c|c|}
\hline & & & \multicolumn{3}{|c|}{ Model 1} & \multicolumn{3}{|c|}{ Model 2} \\
\hline & & & $\mathrm{b}$ & $\beta$ & S.E. & $\mathrm{B}$ & $\beta$ & S.E. \\
\hline \multirow[t]{2}{*}{ Age } & $\rightarrow$ & TOSL & & & & .000 & -.001 & .007 \\
\hline & & $\begin{array}{l}\text { ROSL } \\
\text { Creativity }\end{array}$ & & & & $\begin{array}{l}.000 \\
-.003\end{array}$ & $\begin{array}{l}.004 \\
-.041\end{array}$ & $\begin{array}{l}.007 \\
.006\end{array}$ \\
\hline \multirow[t]{2}{*}{ Gender } & $\rightarrow$ & TOSL & & & & .024 & .018 & .085 \\
\hline & & $\begin{array}{l}\text { ROSL } \\
\text { Creativity }\end{array}$ & & & & $\begin{array}{l}-.014 \\
-.065\end{array}$ & $\begin{array}{l}-.010 \\
-.058\end{array}$ & $\begin{array}{l}.085 \\
.072\end{array}$ \\
\hline \multirow[t]{2}{*}{ Team size } & $\rightarrow$ & TOSL & & & & .067 & $.178^{*}$ & .029 \\
\hline & & $\begin{array}{l}\text { ROSL } \\
\text { Creativity }\end{array}$ & & & & $\begin{array}{l}.046 \\
-.001\end{array}$ & $\begin{array}{l}.121 \\
-.004\end{array}$ & $\begin{array}{l}.029 \\
.025\end{array}$ \\
\hline \multirow[t]{2}{*}{ Course type } & $\rightarrow$ & TOSL & & & & .046 & .034 & .158 \\
\hline & & $\begin{array}{l}\text { ROSL } \\
\text { Creativity }\end{array}$ & & & & $\begin{array}{l}-.040 \\
.201\end{array}$ & $\begin{array}{l}-.030 \\
.177\end{array}$ & $\begin{array}{l}.158 \\
.133\end{array}$ \\
\hline \multirow[t]{2}{*}{ Media richness } & $\rightarrow$ & TOSL & & & & .000 & .004 & .001 \\
\hline & & $\begin{array}{l}\text { ROSL } \\
\text { Creativity }\end{array}$ & & & & $\begin{array}{l}.000 \\
.000\end{array}$ & $\begin{array}{l}-.019 \\
-.005\end{array}$ & $\begin{array}{l}.001 \\
.001\end{array}$ \\
\hline \multirow[t]{2}{*}{ Education level } & $\rightarrow$ & TOSL & & & & .253 & .184 & .160 \\
\hline & & $\begin{array}{l}\text { ROSL } \\
\text { Creativity }\end{array}$ & & & & $\begin{array}{l}.081 \\
-.197\end{array}$ & $\begin{array}{l}.058 \\
-.169\end{array}$ & $\begin{array}{l}.158 \\
.136\end{array}$ \\
\hline Psychological safety & $\rightarrow$ & TOSL & .834 & $.664^{* * *}$ & .124 & .919 & $.705^{* * *}$ & .142 \\
\hline Psychological safety & $\rightarrow$ & ROSL & .898 & $.700 * * *$ & .124 & .923 & $.698 * * *$ & .137 \\
\hline Psychological safety & $\rightarrow$ & Creativity & .175 & .163 & .117 & .175 & .158 & .129 \\
\hline Task leadership & $\rightarrow$ & Creativity & -.010 & -.012 & .140 & .003 & .004 & .148 \\
\hline Relation leadership & $\rightarrow$ & Creativity & .364 & $.435 *$ & .150 & .353 & $.422 *$ & .152 \\
\hline
\end{tabular}


This is an author-produced, peer-reviewed version of this article. The final, definitive version of this document can be found online at Performance Improvement Quarterly, published by Wiley on behalf of the International Society for Performance Improvement. Copyright restrictions may apply. doi: 10.1002/piq.21293

Table 5

Results of Research Models

\begin{tabular}{|c|c|c|c|c|c|c|c|c|}
\hline & & & \multicolumn{3}{|c|}{ TSMM } & \multicolumn{3}{|c|}{ RSMM } \\
\hline & & & $\mathrm{b}$ & $\beta$ & S.E. & $\mathrm{B}$ & $\beta$ & S.E. \\
\hline \multirow[t]{2}{*}{ Age } & $\rightarrow$ & Shared leadership & .000 & -.003 & .007 & .000 & .002 & .007 \\
\hline & & Creativity & -.003 & -.038 & .006 & -.003 & -.041 & .006 \\
\hline \multirow[t]{2}{*}{ Gender } & $\rightarrow$ & Shared leadership & .022 & .016 & .087 & -.012 & -.009 & .085 \\
\hline & & Creativity & -.077 & -.068 & .073 & -.065 & -.058 & .071 \\
\hline \multirow[t]{2}{*}{ Team size } & $\rightarrow$ & Shared leadership & .069 & $.182 *$ & .030 & .045 & .119 & .029 \\
\hline & & Creativity & -.003 & -.010 & .026 & -.001 & -.004 & .024 \\
\hline \multirow[t]{2}{*}{ Course type } & $\rightarrow$ & Shared leadership & .051 & .038 & .161 & -.040 & -.029 & .158 \\
\hline & & Creativity & .172 & .151 & .136 & .201 & .177 & .132 \\
\hline \multirow[t]{2}{*}{ Media richness } & $\rightarrow$ & Shared leadership & .000 & .006 & .001 & .000 & -.021 & .001 \\
\hline & & Creativity & .000 & -.016 & .001 & .000 & -.004 & .001 \\
\hline \multirow[t]{2}{*}{ Education level } & $\rightarrow$ & Shared leadership & .258 & .185 & .163 & .079 & .056 & .158 \\
\hline & & Creativity & -.238 & -.203 & .138 & -.195 & -.167 & .133 \\
\hline Psychological safety & $\rightarrow$ & Shared leadership & .955 & $.702^{* * *}$ & .149 & .924 & $.700^{* * *}$ & .137 \\
\hline Psychological safety & $\rightarrow$ & Creativity & .257 & .226 & .133 & .175 & .159 & .126 \\
\hline Shared leadership & $\rightarrow$ & Creativity & .271 & $.325^{* *}$ & .086 & .354 & $.425 * * *$ & .089 \\
\hline
\end{tabular}

Note: TSMM: Task-oriented Shared Leadership-Mediating Model; RSMM: Relation-oriented Shared LeadershipMediating Model

${ }^{*} p<.05, * * p<.01, * * * p<.001$

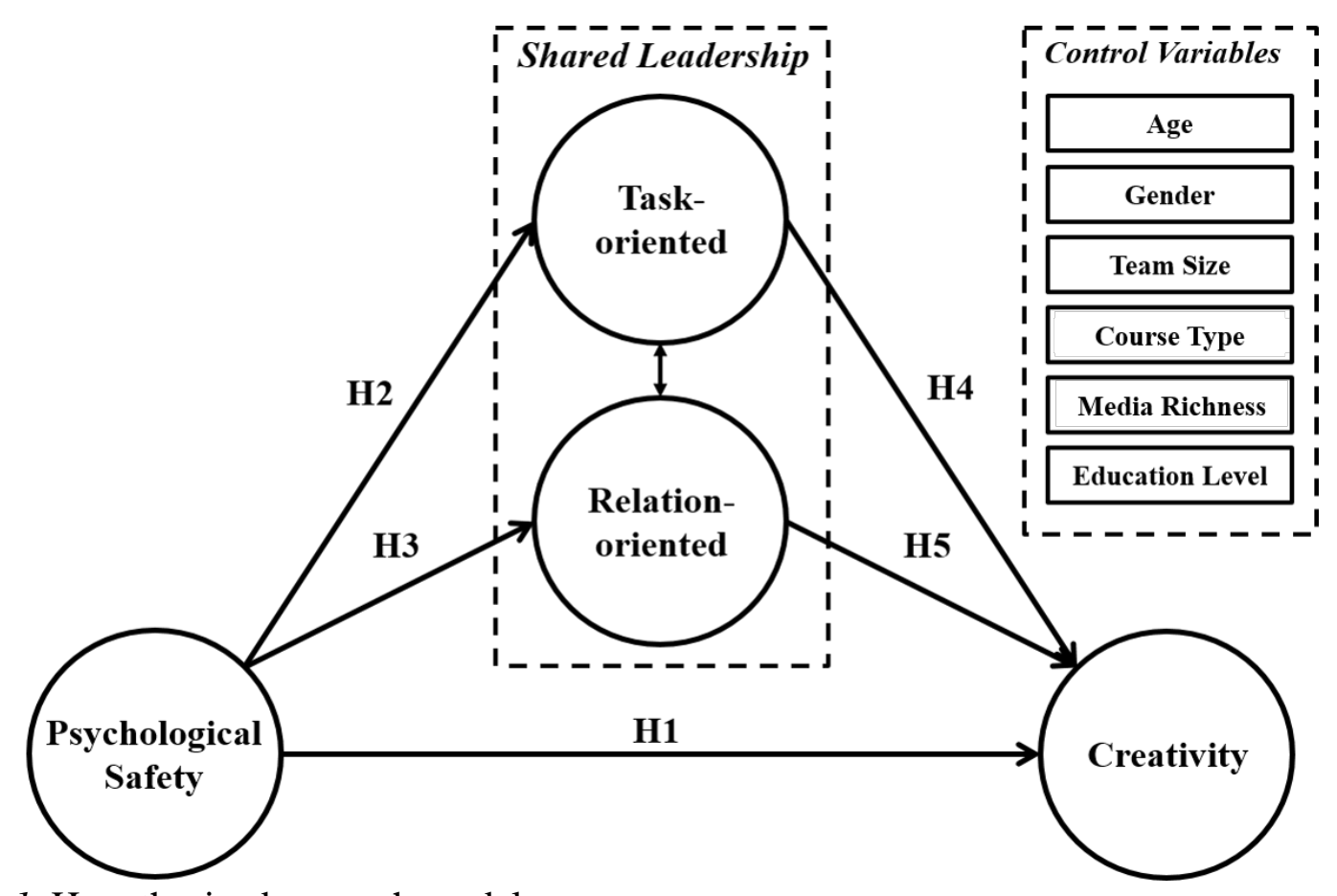

Figure 1. Hypothesized research model 
This is an author-produced, peer-reviewed version of this article. The final, definitive version of this document can be found online at Performance Improvement Quarterly, published by Wiley on behalf of the International Society for Performance Improvement. Copyright restrictions may apply. doi: 10.1002/piq.21293

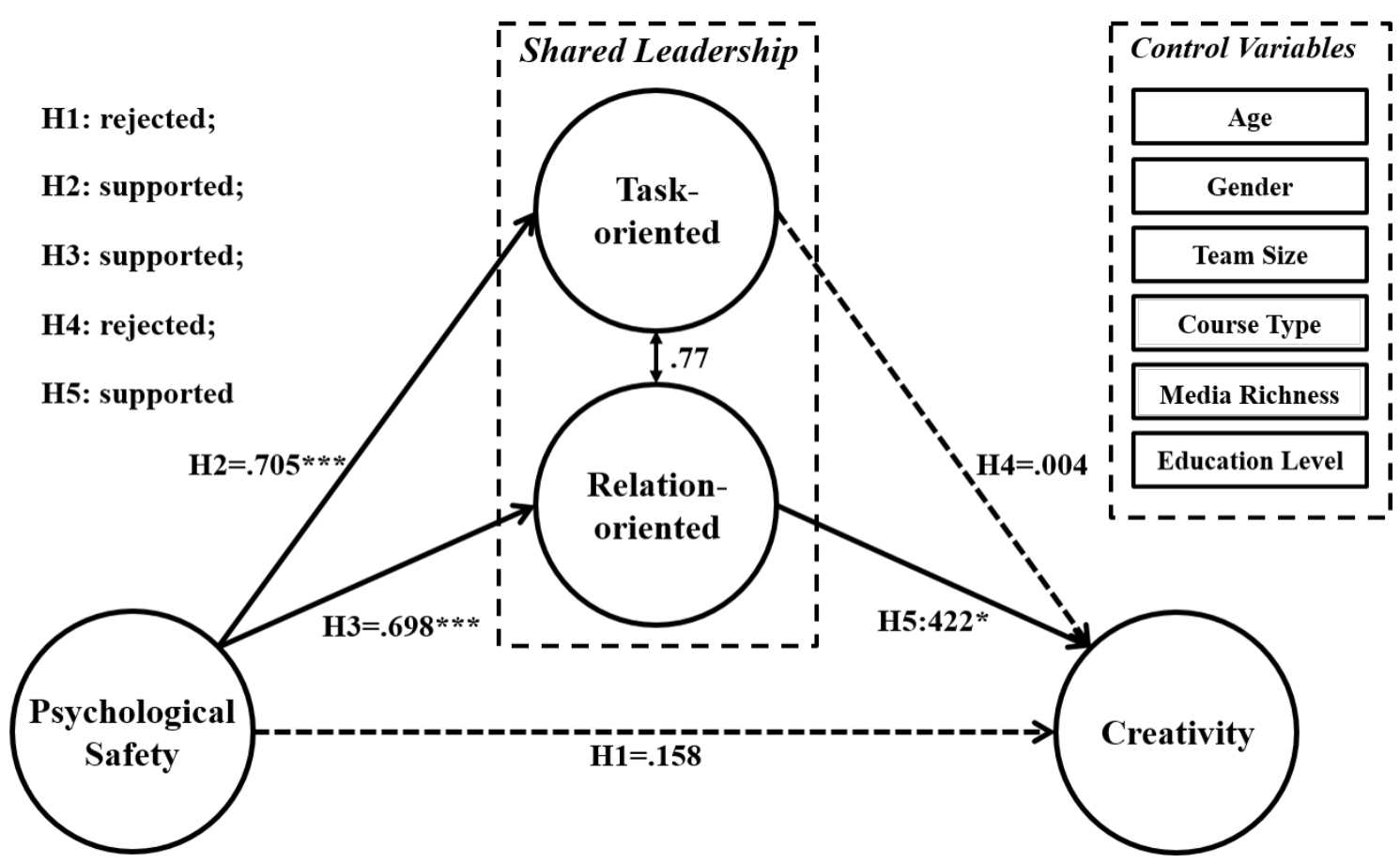

Figure 2. The structural model with testing results with standardized coefficients 